\title{
Geotechnical Investigation of Namar Dam Site by Using Geophysical Tools, Riyadh, Saudi Arabia
}

\author{
Abdullah Al-haj', Nathainail Bashir ${ }^{2}$ \\ 1,2 Department of Geosciences and Geological and Petroleum Engineering, Missouri University of Science and Technology, Rolla, MO, USA
}

\begin{abstract}
Recently, some areas in the Kingdom witnessed collapse of dams, and in others enormous amount of water are being wasted due to the leakage across the dams due to defective structure (cracks and fissures) and bedrock cavities. Therefore, the necessity for geotechnical assessment of the dams and their sites has become very vital and is considered a fundamental step towards the proper protection and long-term performance of these dams. In this respect, geophysical tools are often the most cost-effective and rapid means because of their site accessibility, portability, noninvasiveness, and operator safety. Based on the expected hazards that threaten the existing dams in Riyadh area, the proposed research employed different geophysical techniques to be applied on Wadi Namar Dam site, which are often the most cost-effective and rapid means. Electrical Resistivity Tomography (ERT), Seismic Refraction Tomography (SRT) and Ground Penetrating Radar (GPR) techniques were used for mapping bedrock topography, identifying near-surface karstic terrain and regions of potential weakness (e.g., faults and fractures) in the study site.
\end{abstract}

Keywords: GPR, ERT, Seismic Refraction, Geophysical Investigation, Dam Site, Riyadh, Saudi Arabia.

\section{Introduction}

\subsection{Overview}

The dams in the Kingdom of Saudi Arabia have been built to recharge the groundwater aquifers, secure drinking water to some areas through treatment plants erected thereon, securing irrigation water for agricultural purposes, and protect towns and villages from the danger of flush flood. Recently, some of these dams witnessed partial collapse, and in others, amount of water is being wasted due to the leakage across the dams due to defective structure (cracks and fissures) and bedrock fractures and cavities. Most of these dams were built since decades, therefore, a continuous and adequate investigation for the dam site and structure is very important for the dam safety management, long-term performance, and maintenance of these dams. In this respect, geophysical tools are cost-effective, and speed means because of their site accessibility, portability, noninvasiveness, and safety.

The use of geophysical methods for subsurface characterization study of a dam site is increasingly becoming popular all over the world and has the possibility to give an image of the subsurface to the geologists and geotechnical engineers (Benson et al., 1984; Goldstein, 1994; Benson and Yuhr, 1995, 2002). The subsurface characterization of the dam site including bedrock depth, rock type, layer boundaries, groundwater flow, locating fractures, weakness zones, detecting cavities caused by sinkholes will be detected using the electrical resistivity tomography (ERT), Ground Penetrating Radar (GPR) and Seismic Refraction Tomography (SRT) Method. By Utilizing ERT and GPR, seepage pathways through the rock formations under and around the dam foundation can be detected and mapped (e.g. Corwin, 2007; Dahlin and others, 2008) through the use of the low resistivity anomalies associated with active seepage paths. These two methods depend directly on the electrical conductivity that is in direct relation to the ground moisture (McCann and Forde, 2001; Polder, 2001), indicating the areas that are more susceptible to infiltration or leakage. SRT method is the most frequently used geophysical means of investigating at dam sites. Multichannel surveys on land produce detailed profiles of depths to bedrock, overburden conditions and the competency of the bedrock.

\subsection{Site description}

Wadi Namar is located at the southern part of Riyadh, Kingdom of Saudi Arabia. It is located at an elevation of 626 meters above sea level and Its coordinates are $24^{\circ} 32^{\prime} 18^{\prime \prime} \mathrm{N}$ and $46^{\circ} 34^{\prime} 60^{\prime \prime} \mathrm{E}$ in DMS (Degrees Minutes Seconds) or 24.5383 and 46.5833 (in decimal degrees). A wadi is a valley or ravine, bounded by relatively steep banks, which in the rainy season becomes a watercourse; found primarily in North Africa and the Middle East (figure.1). (getamap.net). 


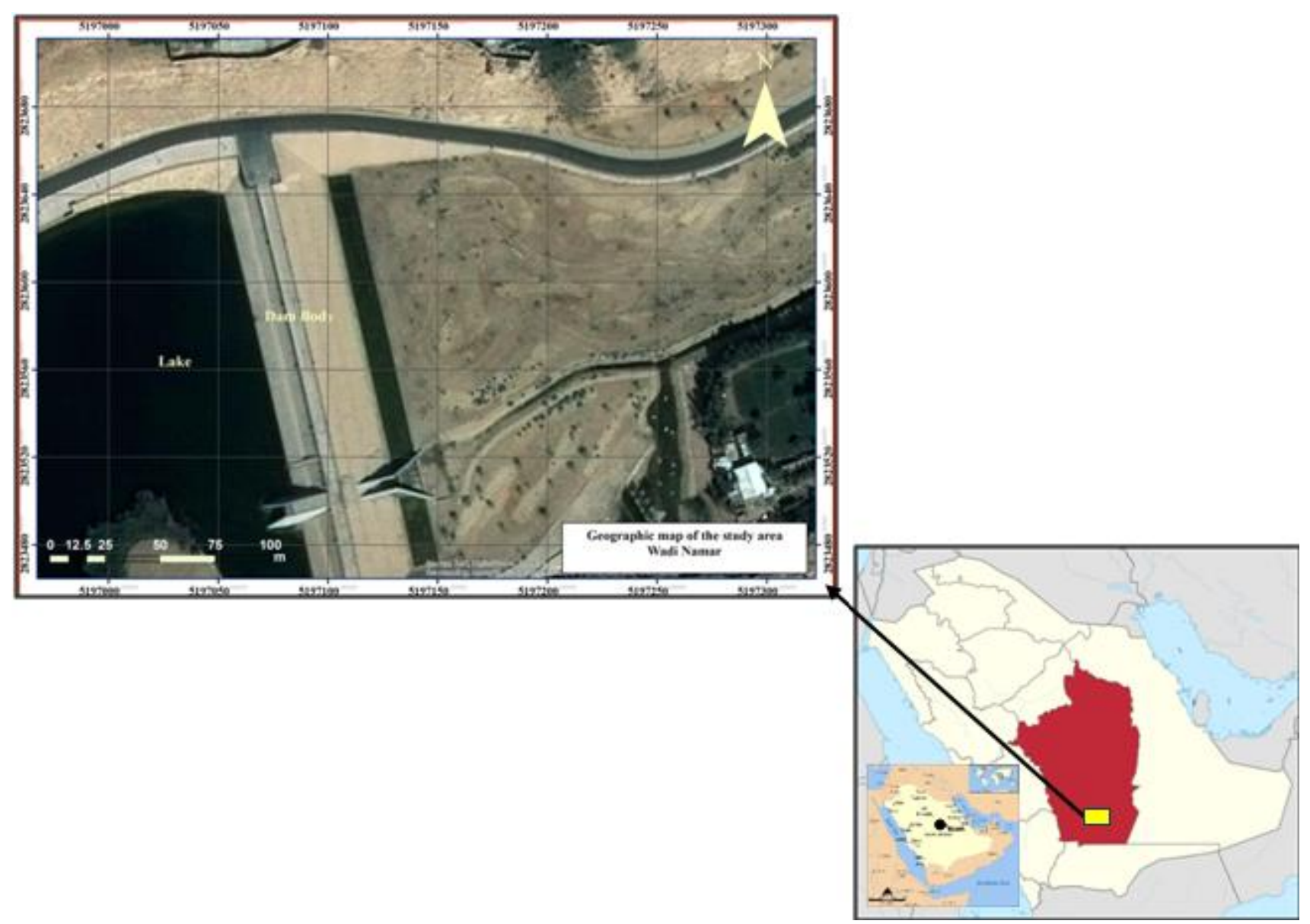

Figure 1: Location map of study area.

\subsection{Geological Setting}

The Arabian Peninsula is composed of two structures completely different, the first is the Arabian Shield, which covers an area of about $2 / 5$ of the Arabian Peninsula to the west, and the second basin sedimentary rocks to the east of the Arabian Shield. It consists of the Arabian Shield rock solid base rocks belonging to the old age (pre-Cambrian), which topped the basin sedimentary rock layers of the Paleozoic and Mesozoic) and Cenozoic. The Mesozoic rocks that most rocks Riyadh region back to it from the thick deposits of successive layers of the continental rocks and sediments shallow water facies dominated by calcareous rocks, where a huge curved form a belt in the center of the
Arabian Peninsula. These layers reflect the topography of the base (Arabian Shield), where classes extend to the east Askew year is estimated at about one degree, has been to clarify the geology of Riyadh and the preparation of geological maps in the light of previous studies, in addition to the analysis of the information reached by the study of high ground water level. The study Area is mainly composed of Alluvial deposits of nested clay with mixed layers of silt and gravel, and Arab Formation which contains cracked limestone and Jubaila Formation which dominated by calcareous rocks and fine crystals that also interfere with coarse limestone rock crystals as shown in (figure.2).

Volume 6 Issue 12, December 2017

www.ijsr.net 
International Journal of Science and Research (IJSR)

ISSN (Online): 2319-7064

Index Copernicus Value (2016): 79.57 | Impact Factor (2015): 6.391

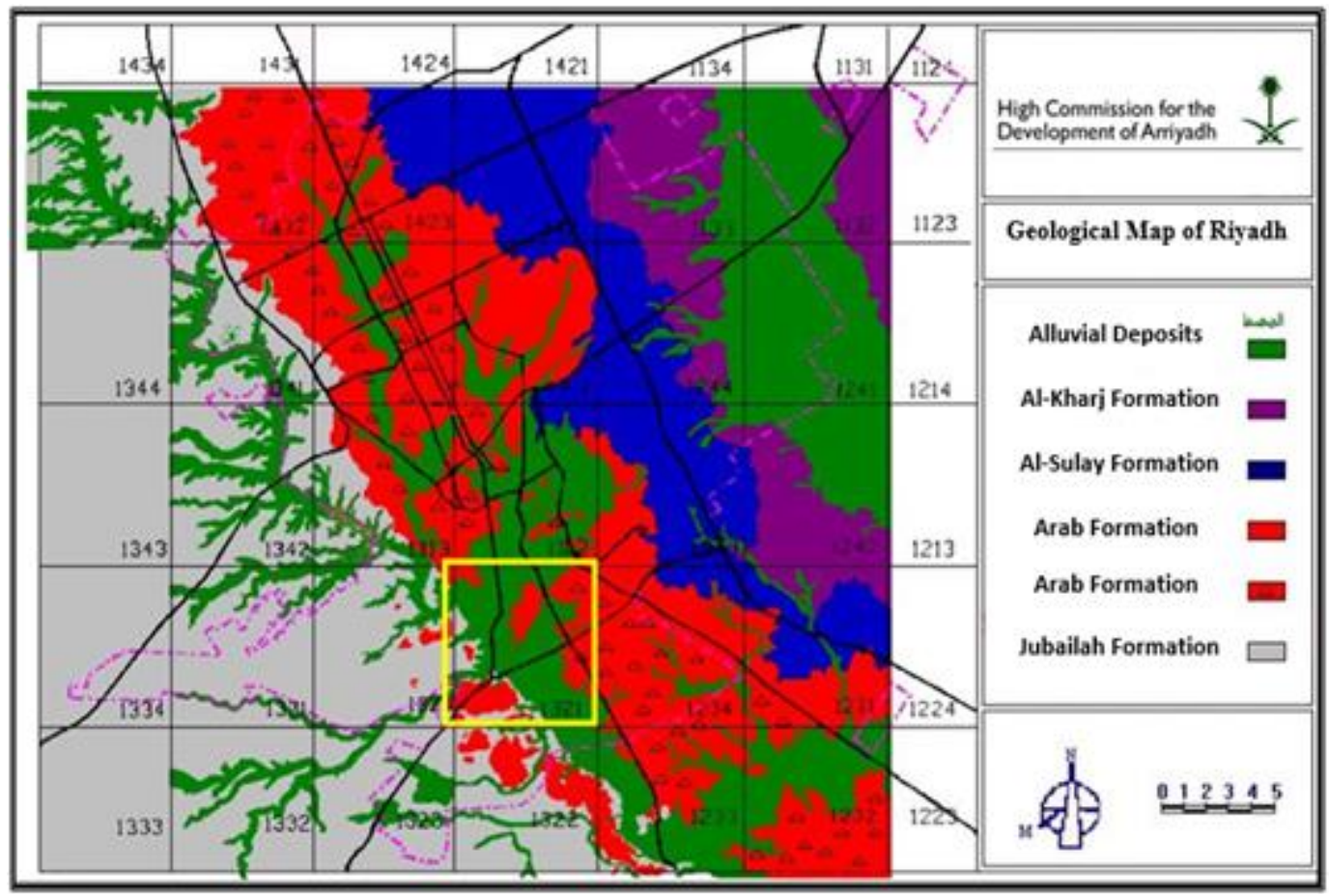

Figure 2: Geological map of study area.

(High Commission for Development of Arriyadh-http://www.arriyadh.com/eng/ada/index.aspx)

\section{Methodology}

In this study, three geophysical tools were used to detect the subsurface structures and seepages of ground water in the dam site. The seismic method is the most commonly conducted geophysical survey for engineering investigations. GPR is an electromagnetic (EM) geophysical method for high-resolution detection, imaging and mapping of subsurface soils and rock conditions, as well as electrical resistivity for detection of cavities caused by sinkholes. The integrated geophysical techniques provide a clear image of the subsurface materials and correlation of data to decrease the interpretation ambiguity.

\section{Data acquisition}

\subsection{Ground penetrating radar acquisition}

GPR data were collected for 3 traverses using a GSSI SIR3000 control unit with a $400 \mathrm{MHz}$ antenna mounted on a push cart (figure.3). A dielectric constant of 8 was used given the target and target area. The selections of these parameters were pre-determined based on the target size, target depth, and the geology of the area. Given the target size $48 \mathrm{Scan} / \mathrm{unit}$ (ft.) and $512 \mathrm{samples} / \mathrm{scan}$ was used. The three traverses were conducted as two parrell and one

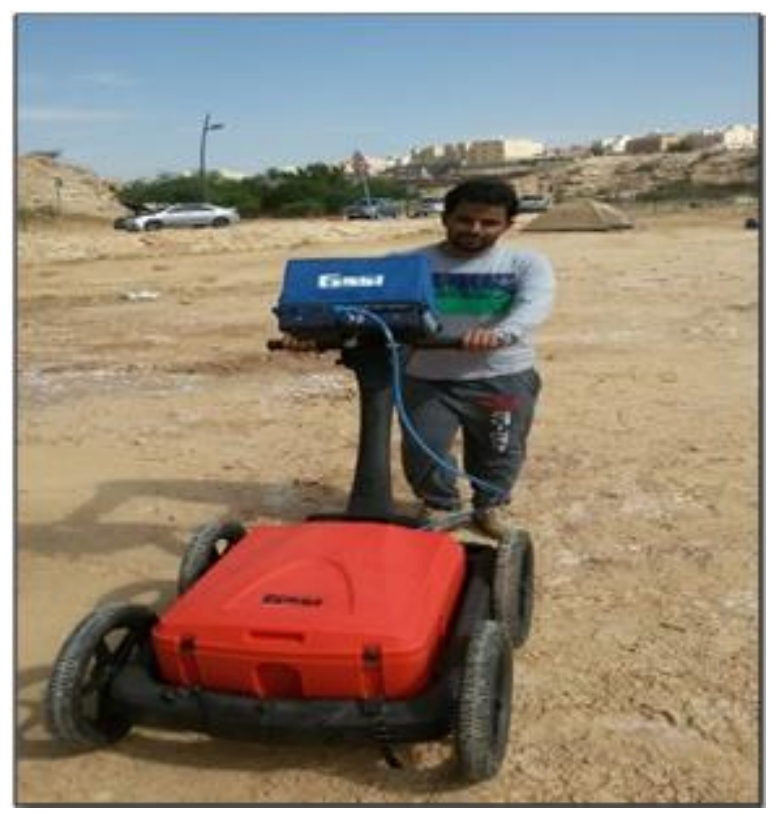

Figure 3: GPR unit used for data acquisition. perpendicular to the dam site as illustrated in (figure.4). 
International Journal of Science and Research (IJSR)

ISSN (Online): 2319-7064

Index Copernicus Value (2016): 79.57 | Impact Factor (2015): 6.391

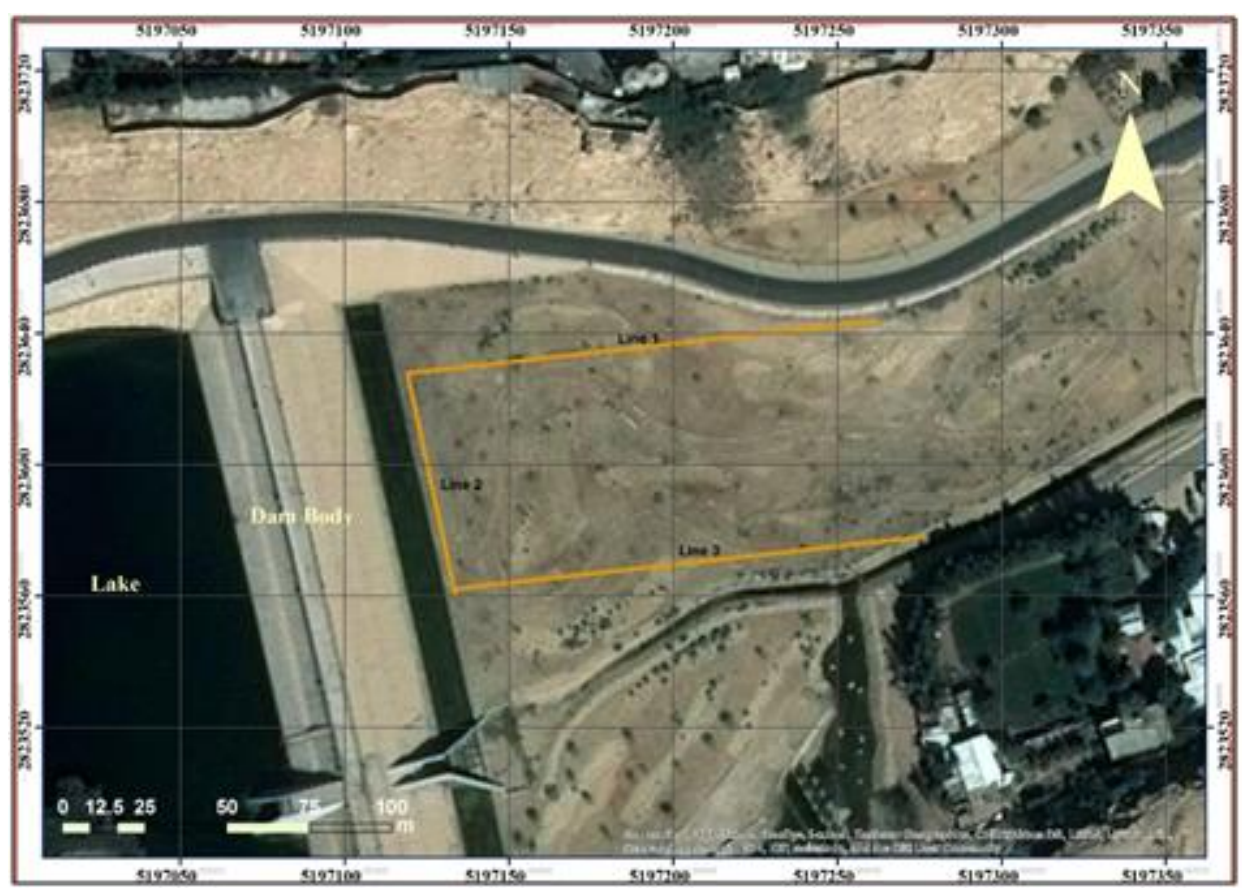

Figure 4: Marked lines representing the GPR traverses next to the dam site.

\subsection{Electrical Resistivity and Seismic refraction} acquisition

ERT and Seismic Refraction equipment (figure.5-6) were used to acquire data along two traverses; one is parallel, and

the other is perpendicular to the dam site as shown in (figure.7).

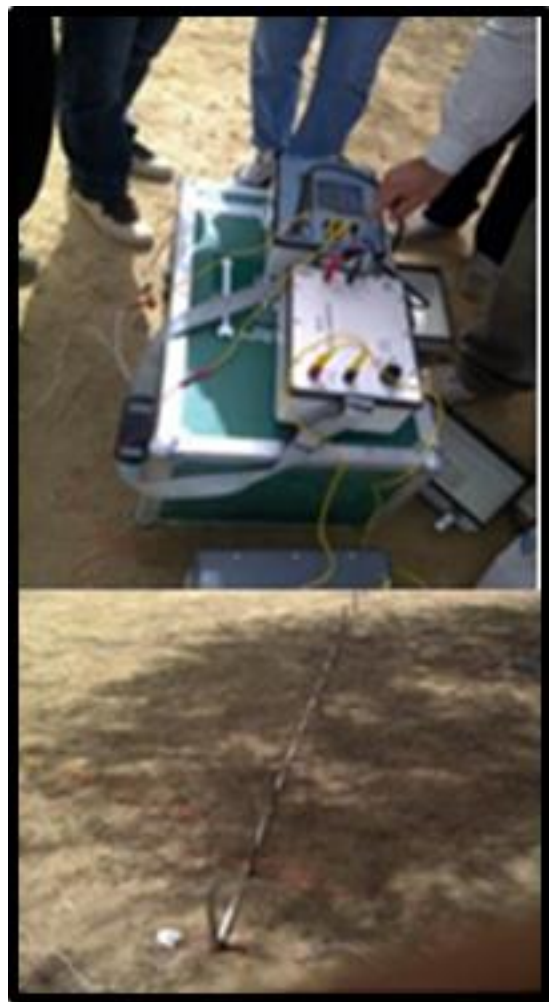

Figure 5: Electrical Resistivity Tomography

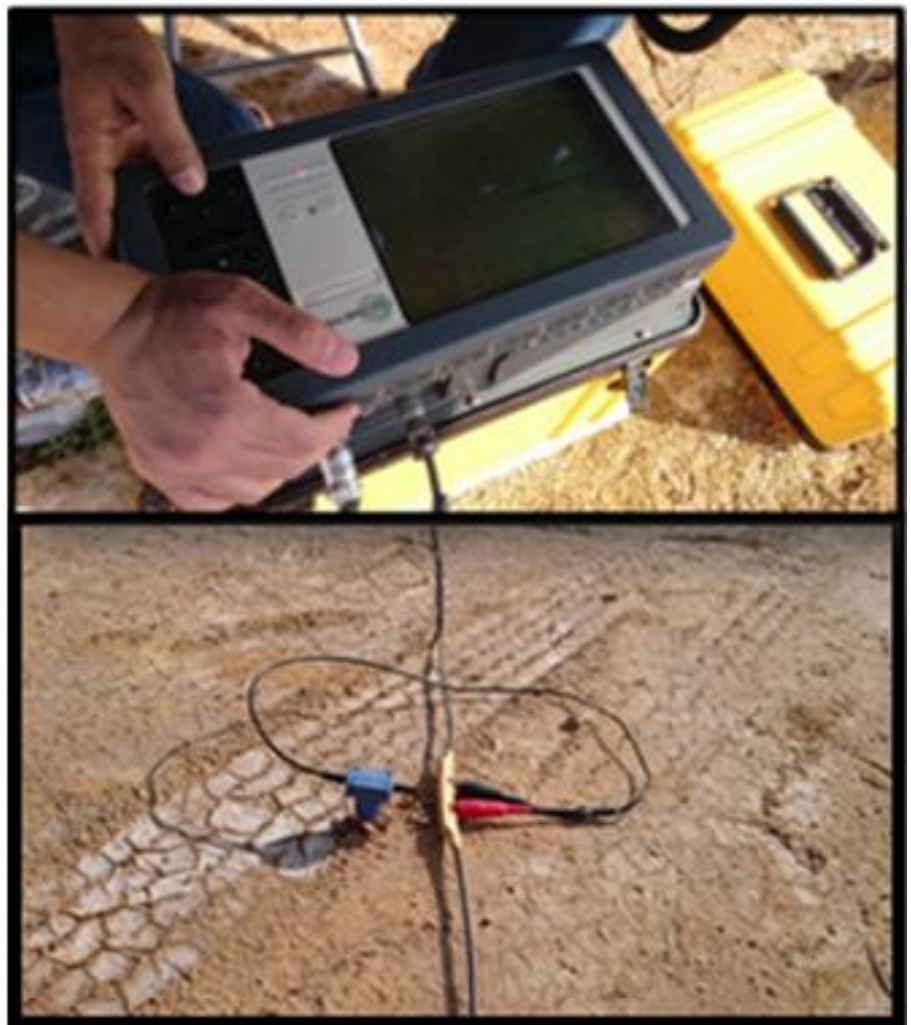

Figure 6: Seismic Refraction Survey

Volume 6 Issue 12, December 2017 www.ijsr.net 


\section{International Journal of Science and Research (IJSR) \\ ISSN (Online): 2319-7064}

Index Copernicus Value (2016): 79.57 | Impact Factor (2015): 6.391

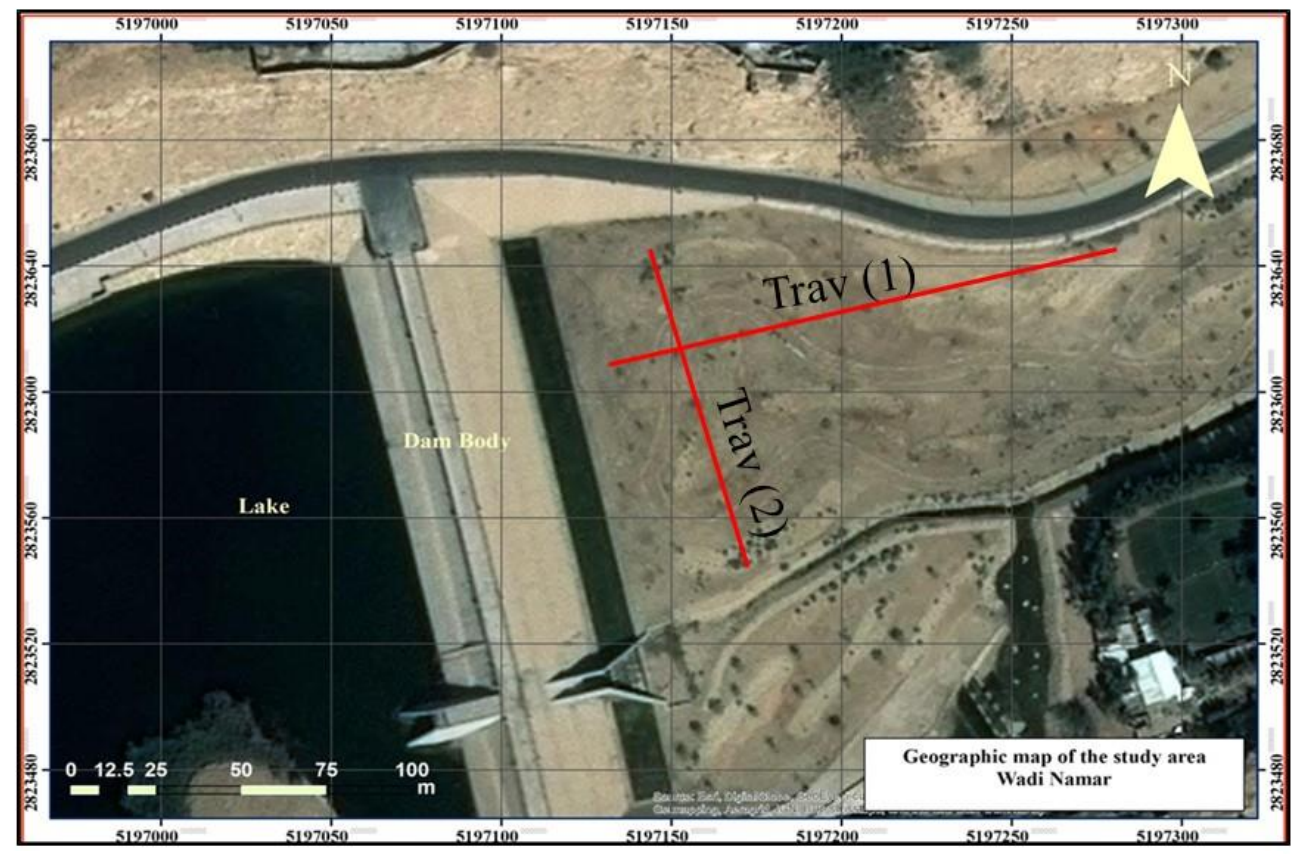

Figure 7: Red lines representing the ERT and Seismic Refraction traverses (Trav (1), (2); Trav (1) perpendicular and Trav (2) parrell to the dam site.

\section{Results and Discussions}

The interpreted data of the study Area is mainly characterized by the presence of weathered and fractured Limestone layer that overlain by alluvial soft sediments. According to the Seismic Refraction Survey, the weathered and fractured layer attain seismic velocity ranged from 1.13 to $3.00 \mathrm{~km} / \mathrm{s}$ and thickness ranged from 5 to $10 \mathrm{~m}$ as shown in (figure.8(a-b)). The geoelectric 2D Resistivity imaging shows the existence of void and cavity structures. These cavity structures are either filled with air that show high resistive anomalies and others attain relatively low resistivity that show anomalies that could be interpreted as cavities filled with wet clayey sediments (figure.9). To the west of the geoelectric cross section there is an abrupt change in the resistivity values indicating the presence of fault structure. These cavity structures are confirmed and shown clearly with the GPR sections (figure.10(a-b)).

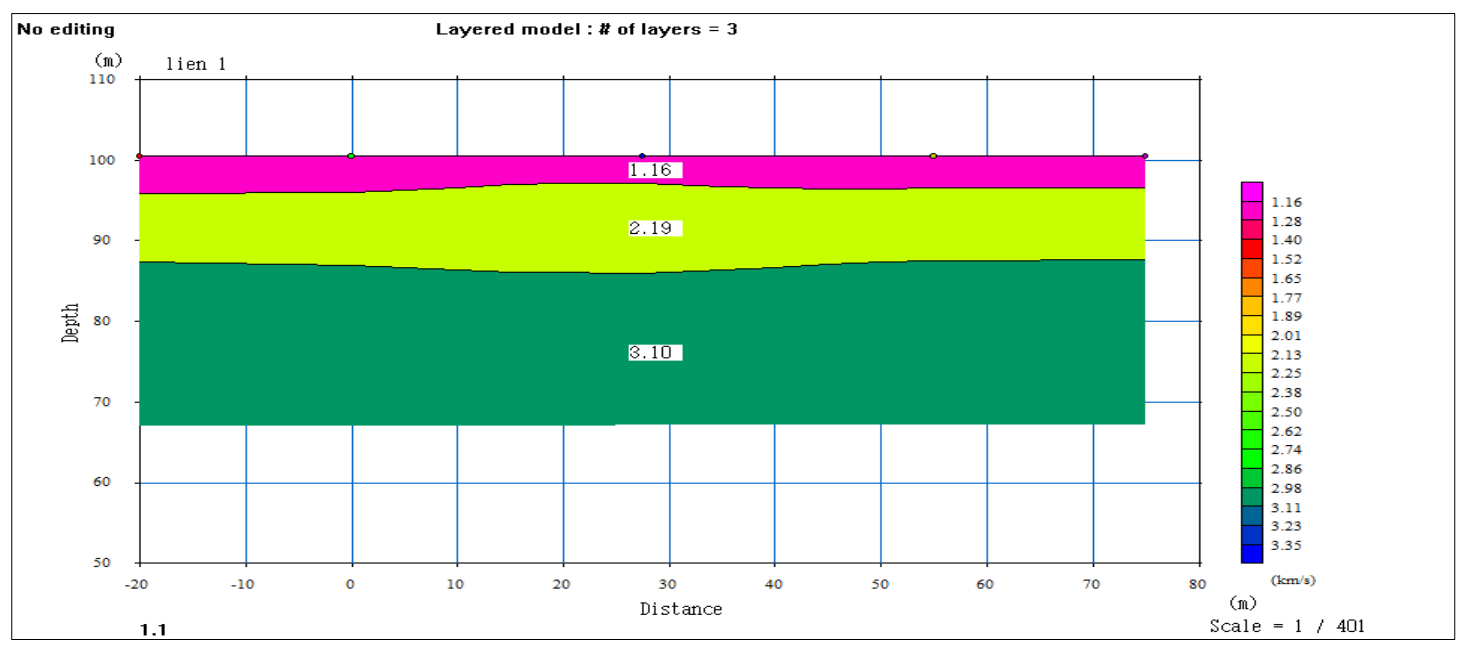

Figure 8 (a): Seismic Section for the First profile (Perpendicular to dam body)

Volume 6 Issue 12, December 2017 www.ijsr.net 
International Journal of Science and Research (IJSR)

ISSN (Online): 2319-7064

Index Copernicus Value (2016): 79.57 | Impact Factor (2015): 6.391

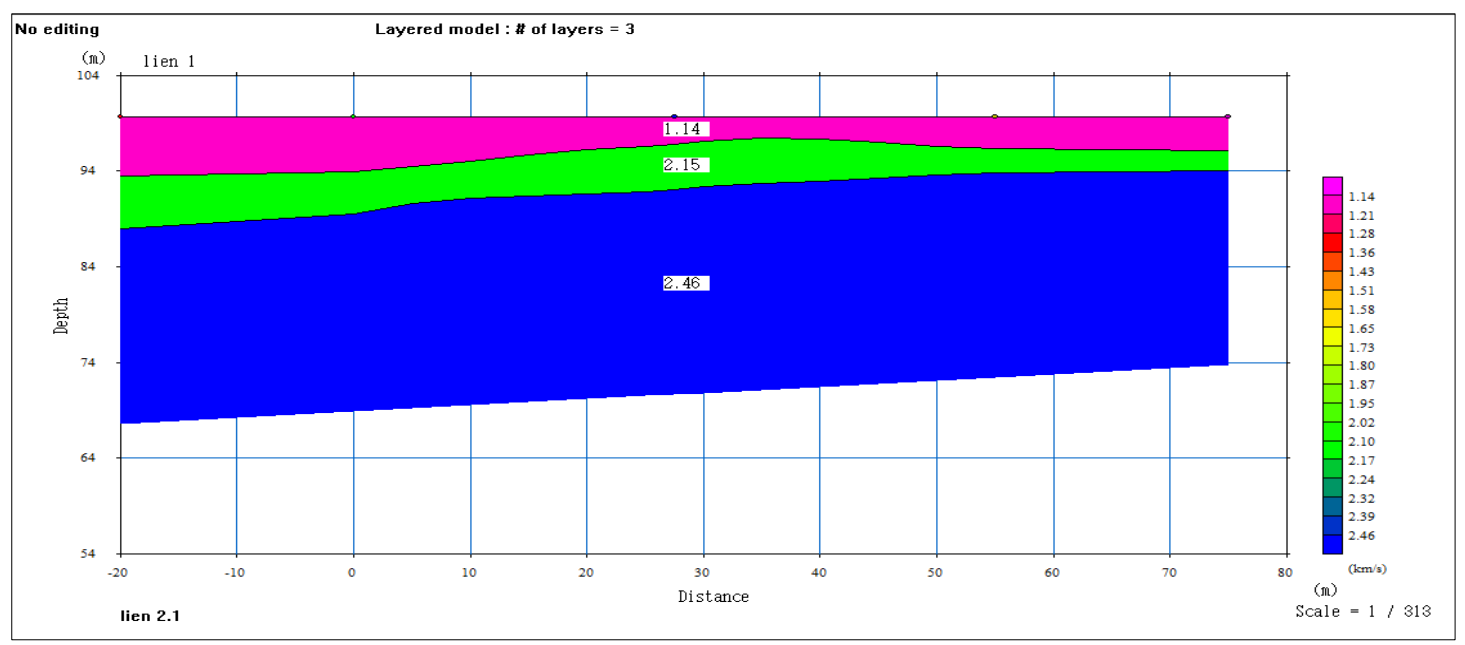

Figure 8 (b): Seismic Section for the Second profile (Parallel to dam body)

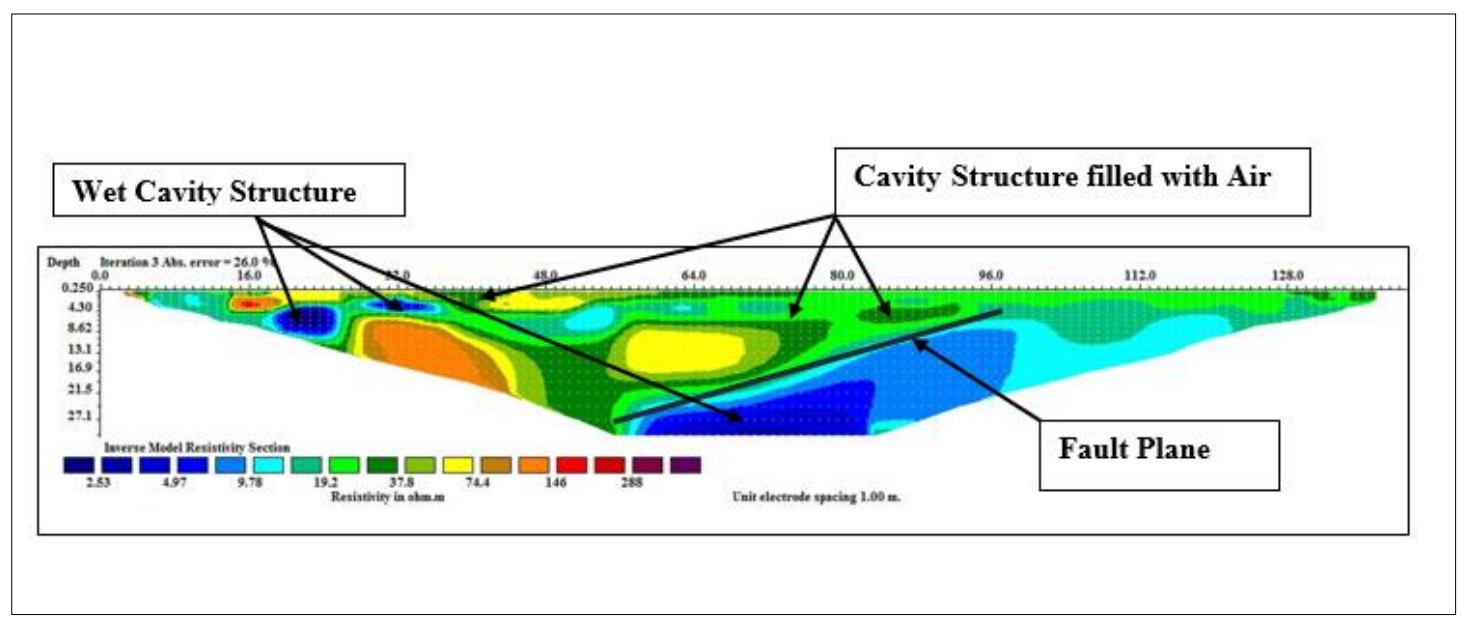

Figure 9:2D Electrical Resistivity Section

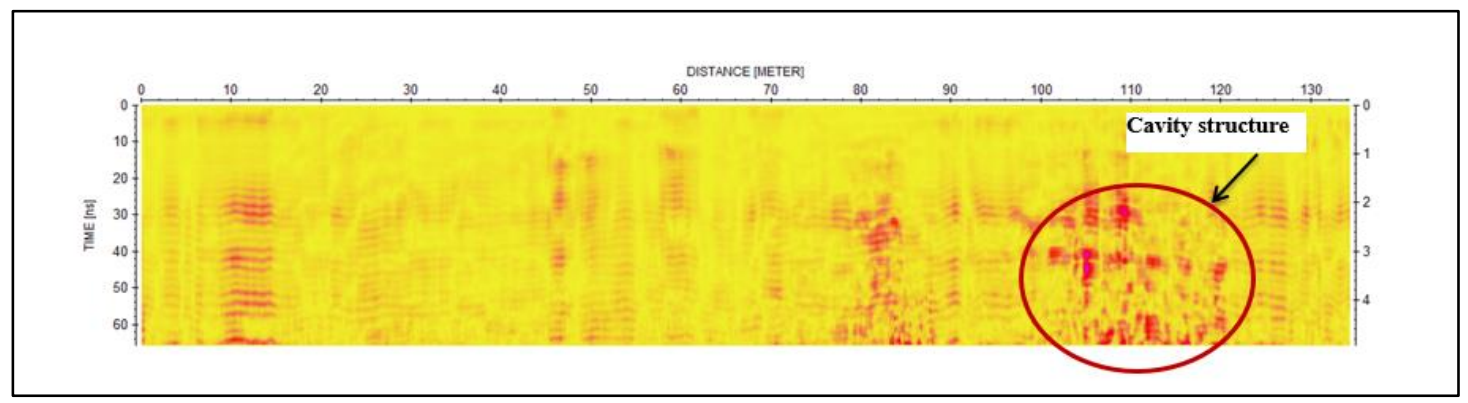

Figure 10 (a): GPR Section for the First profile (parallel to dam body)

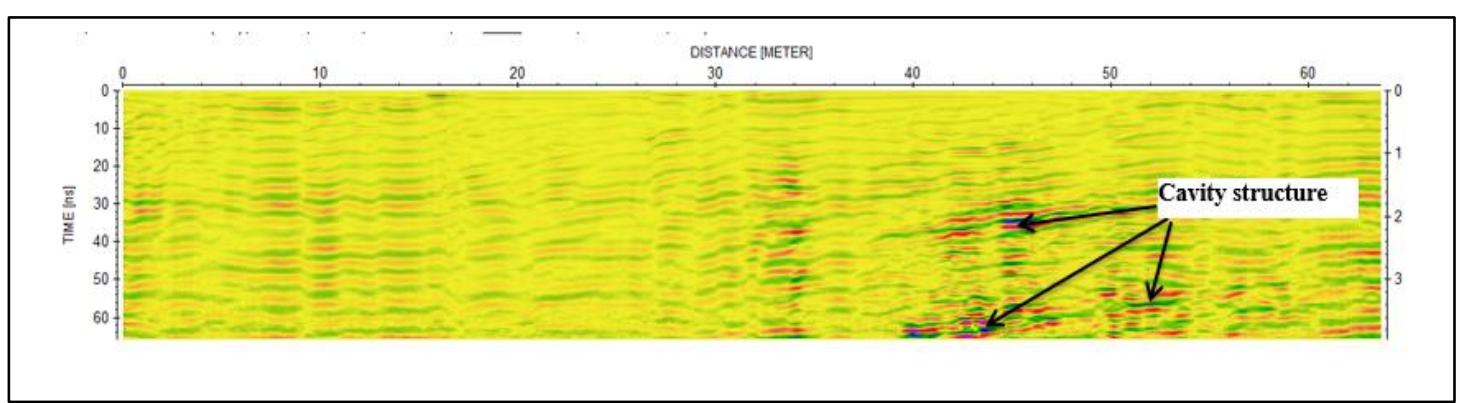

Figure 10 (b): GPR Section for the Second profile (Perpendicular to dam body)

Volume 6 Issue 12, December 2017 www.ijsr.net

Licensed Under Creative Commons Attribution CC BY 


\section{International Journal of Science and Research (IJSR) \\ ISSN (Online): 2319-7064}

Index Copernicus Value (2016): 79.57 | Impact Factor (2015): 6.391

\section{Conclusion}

In general, from the previous interpretation of results illustrating the detection of fractures, cracks and voids in the dam structure and delineation the pathways of groundwater seepage in the dam site as well as mapping bedrock topography, faults, weak zones, cavities, and near-surface karstic sinkholes in the dam site. It could be concluded that this site is affected by the weathered fractured system and presence of cavities that facilitate the vertical seepages of ground water from the dam site.

\section{Acknowledgements}

The Authors thank Pro. Elkheder H. Ibrahim and Prof. Kamal Hassanien faculty of Geophysics and Geology Dept. at King Saudi University for their Supervision and carrying out the field work for this study.

\section{References}

[1] Abdeltawab, S. (2013). Karst Limestone Geohazards in Egypt and Saudi Arabia. International Journal of Geoengineering Case histories, http://casehistories.geoengineer.org, Vol.2, Issue 4, PP.261, 264.

[2] Alhaj, A.and Mudhhi, H. (2015). Geotechnical investigation of Namar dam site using geophysical tools poster at the eleventh geological conference, Riyadh area, Saudi Arabia.

[3] Alsharhan, A.and Nairn, A., Sedimentary Basins and Petroleum Geology of the Middle East (2003). , Elsevier Science B.V., PP.250-253.

[4] Ammar A. Amin And Khalid A. Bankher.1997, Karst Hazard Assessment of Eastern Saudi Arabia., Kluwer Academic Publishers, Netherlands, PP.22-23

[5] Biswas, A.K., and Charttergee, S., 1971. Dam Disasters An Assessment. Eng. J. (Canada), 54(3): 3-8.

[6] Goldstein NE (1994). Expedited site characterization geophysics: Geophysical methods and tools for site characterization. Prepared for the U.S. Department of Energy by Lawrence Berkeley Laboratory, Univ. of California. 124 p.

[7] Lawrence B. Conyers, Basics of GPR Method and Theory, University of Denver. http://mysite.du.edu/ lconyer/

[8] Panthulu, T.V., Krishnaiah, C. and Shirke, J.M. 2001. Detection of seepage paths in earth dams using selfpotential and electrical resistivity methods. Engineering Geology 59, p 281-295.

[9] Powers, R. W., Ramires, L. F., Redmond, C. D., and Elberg, E. L.: 1966, Geology of the Arabian Peninsula: Sedimentary Geology of Saudi Arabia, U.S. Geological Survey Professional Paper 560-D, PP.D53-D60.

\section{Author Profile}

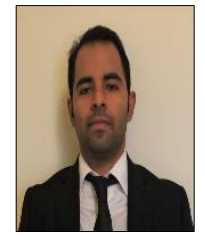

Abdullah Al-haj received his B.S. of Applied Geophysics from King Saud University in 2015 with the First Class Honor and he is currently pursuing his M.S. in Geological Engineering at Missouri University of Science and Technology. He has sufficient work and training experiences of near surface geophysical applications. In addition, he participated in many national and international conferences.

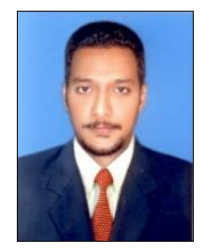

Nathanial Bashir is a $\mathrm{PhD}$ candidate earning his degree in Geological Engineering from Missouri University of Science and Technology. His $\mathrm{PhD}$ dissertation is "using the integral geophysical methods (ERT, MASW, GPR's, Gravity, Marine Geophysics) to find the subsurface geology of southwest Missouri". He loves being in the field and seeing what he studies in classes, this is the reason he is more at home in the field than in the classroom. Besides his research, he serves the Council of Graduate Students at Missouri S\&T as a Department Representative and Campus Committee Representative 